\title{
mda-7/IL-24 induces apoptosis in human GBC-SD gallbladder carcinoma cells via mitochondrial apoptotic pathway
}

\author{
JIANGUANG JIA, SONGGANG LI, WEI GONG, JING DING, CUIFU FANG and ZHIWEI QUAN \\ Department of General Surgery, Xinhua Hospital, Shanghai Jiao Tong University School of Medicine, \\ 1665 Kongjiang Road, Shanghai 200092, P.R. China
}

Received April 8, 2010; Accepted July 26, 2010

DOI: 10.3892/or_00001061

\begin{abstract}
IL-24 has tumor-suppressor activity in a broad spectrum of human cancer cells. However, the therapeutic effect of the recombinant human IL-24 protein on human gallbladder carcinoma has rarely been explored. In this study, we used a human gallbladder carcinoma cell line (GBC-SD) to explore the effect of adenovirus-mediated IL-24 (Ad-IL24) gene therapy on GBC-SD cells. We show that AdIL24 treatment of GBC-SD cells in vitro conspicuously induced apoptosis of GBC-SD cells. We also demonstrate that the in vivo treatment of GBC tumor-bearing athymic nude mice intratumorally injected with Ad-IL24 significantly suppressed GBC growth. To further explore the mechanism that mda-7/IL-24 utilized in tumor cell apoptosis, we examined molecules and pathways involved in apoptotic regulation and found that Ad-IL24 induced the downregulation of anti-apoptotic gene Bcl-2 and the release of cytochrome c, which subsequently activated caspase-9, caspase-3 and PARP to induce apoptosis. In summary, adenovirus (AdV)-mediated IL-24 overexpression exerted potent antitumor activity via stimulating mitochondrial apoptotic pathway in GBC-SD. Therefore, mda-7/IL-24 has the potential to serve as a tool for targeted gene therapy in the treatment of gallbladder cancer.
\end{abstract}

\section{Introduction}

Gallbladder carcinoma (GBC) is the fifth most common malignant tumor of the digestive system and the most common

Correspondence to: Dr Zhiwei Quan, Department of General Surgery, Xinhua Hospital, Shanghai Jiao Tong University School of Medicine, 1665 Kongjiang Road, Shanghai 200092, P.R. China

E-mail: zhiweiquan@yahoo.com.cn

Abbreviations: GBC, gallbladder carcinoma; MOI, multiplicities of infection; GFP, green fluorescent protein; Z-VAD-FMK, Z-ValAla-DL-Asp-fluoromethylketone; MTT, 3-(4,5-dimethylthiazol-2yl)-2,5-diphenyltetrazolium bromide

Key words: mda-7/IL-24, apoptosis, gene therapy, gallbladder carcinoma malignant neoplasm of the biliary tract. Although rarely reported in Europe and the United States, GBC is relatively common in South America, India and Poland (1). Over the past decades, the incidence rate of GBC has increased in China. The survival rate has not improved even after radical operations were performed (2) because of late diagnosis, high incidence of post-surgical regional recurrence and distant metastases. Additionally, chemotherapy and radiotherapy have limited efficacy on GBC and generally GBC is considered as a 'chemo-resistant' tumor, which was evidenced by low response rates and no demonstrated survival benifit (3). Many researches have been trying hard to find approaches to benefit patients with GBC but only achieved limited progress. It is imperative to identify novel therapeutic measures to enhance the therapeutic effect and improve the survival of patients with GBC.

The melanoma differentiation associated gene-7 (mda-7 gene) [renamed interleukin 24 (IL-24)] was isolated from human melanoma cells induced to terminally differentiate by treatment with fibroblast IFN and mezerein (4). This novel cytokine is classified as a member of the interleukin-10 (IL-10) gene family (5). Overexpression of mda-7/IL-24, by use of a recombinant adenovirus Ad.mda-7, inhibits the growth and kills numerous types of human tumor cell lines including melanoma, pancreatic, glioblastoma, gastric carcinoma, and laryngocarcinoma resulting in tumor-specific growth arrest, without exerting deleterious effects in normal melanocytes, astrocytes and human epithelial or fibroblast cells (6-11). It also showed potent cancer-specific apoptosis-inducing ability and tumor growth-suppressing properties in multiple human tumor xenograft animal models. mda-7/ IL-24 is under evaluation in a phase I clinical trial in patients with advanced melanoma cancers (12).

Nevertheless, the detailed apoptotic pathways in Ad.mda-7 causing tumor cell death are not fully understood. Moreover, recent studies showed the mechanism of Ad.mda-7 induced apoptosis varies in different tumor cell lines. It causes some cancer cells specific apoptosis through the autocrine regulation of mda-7 (13), chronic lymphocytic leukemia B cells through dephosphorylation of STAT3 (14), ovarian cancer cells mainly through the fas/fasL pathway (15), malignant cerebral glioma through the caspase-, cathepsin- and PERKdependent pathway (16), melanoma cells through class I interferon-regulated signaling pathways (17) and malignant renal carcinoma cells through ceramide/CD95/PERKdependent mechanism (18). Other studies have shown that 
intracellular mda-7/IL-24 is located in the endoplasmic reticulum (ER) and Golgi complex and that it may be involved in the apoptosis signal transduction pathway that is mediated by ER stress (19). Thus, mda-7/IL-24 lethality seems to occur by multiple distinct pathways in different cell types. We hypothesized that AdIL-24 could induce apoptosis of GBC in vitro and inhibit grafted tumor growth in vivo. In addition, we further investigated the mechanism of AdIL-24 induced apoptosis in GBC-SD cells.

\section{Materials and methods}

Cell culture and treatment. The human gallbladder carcinoma cell line GBC-SD was purchased from the Cell Bank of the Chinese Academic of Sciences (Shanghai branch). Cells were cultured at $37^{\circ} \mathrm{C}$ in a humidified atmosphere containing 5\% $\mathrm{CO}_{2}$ in RPMI-1640 medium (Gibco BRL, Carlsbad, CA) with $2 \mathrm{mM}$ gut amine. The medium was supplemented with $10 \%$ fetal bovine serum (Gibco BRL), $100 \mathrm{IU} / \mathrm{ml}$ penicillin and $100 \mu \mathrm{g} / \mathrm{ml}$ streptomycin. At $24 \mathrm{~h}$ after cell seeded in the culture dish, the recombinant adenovirus vector at different multiplicities of infection (MOI) transfected the GBC-SD cells. At 30 min before the recombinant adenovirus vector transfection, the pancaspase inhibitor Z-Val-Ala-DLAsp-fluoromethylketone (Z-VAD-FMK; Alexis Biochemicals, San Diego, CA) $30 \mu \mathrm{M}$ was added.

Construction of recombinant adenovirus. Replication-defective adenovirus-5 (Ad5) encoding mda-7/IL-24 (Ad.IL-24) was constructed using the AdEasy ${ }^{\mathrm{TM}}$ Adenoviral Vector System (Quantum Biotech, Montreal, Canada). Briefly, recombinant adenovirus plasmid pAd.mda-7 carrying human mda-7/IL-24 cDNA was constructed and transfected into the human embryonic kidney 293 (QBI-293A) cells by Lipofectamine ${ }^{\mathrm{TM}}$ 2000 reagent (Invitrogen, Carlsbad, CA), leading to the formation of the recombinant adenoviruses Ad.IL-24. The virus containing this construct was isolated using plaque screening, purification and amplification. At the same time, recombinant adenovirus Ad.GFP carrying Green fluorescent protein (GFP) was constructed as a control.

MTT assay. Cytotoxic activity of AdGFP/IL-24 was determined based on cycotoxicity to GBC-SD cells, using the MTT assay. Briefly, cells were harvested and dispensed in 96-well culture plates in $100 \mu 1$ medium at a concentration of $10^{4}$ cells per well. After 24 h, Ad.IL-24, Ad.GFP, Ad.IL-24 or PBS was added at MOI 10 and cells were cultured for another 3 days. Ten microliter 3-(4,5-dimethylthiazol-2-yl)2,5-diphenyltetrazolium bromide (MTT) (Roche Diagnostics $\mathrm{GmbH}$ Co., Germany) was added to each well. After $4 \mathrm{~h}$ incubation at $37^{\circ} \mathrm{C}$, supernatants were removed and replaced by $150 \mu 1$ dimethyl sulfoxide. The optical density at $490 \mathrm{~nm}$ (OD490) of each well was measured using an automated microplate reader (Bio-Rad Model 550, Microplate Reader, Hercules, CA).

RNA isolation and RT-PCR. After cells infected with Ad.GFP and Ad.IL-24 (MOI=10), respectively, cells were harvested at $72 \mathrm{~h}$ after infection, total RNA was extracted from cells using the Takara A mini kit (Japan) according to the manu- facturer's protocol. Primers used in PCR were designed according to the reported IL-24 cDNA sequence. The primer sequences were 5'-CGTGTCACAACTGCAACC-3' (forward) and 5'-CTGGGCCAAGAATGGG-3' (reverse). The primer sequences of $ß$-actin were 5'-CCTTCCTGGGCAATGGAGT CCT-3' (forward) and 5'-GGAACAATGATCTTGATCTT-3' (reverse). The reaction mixture with corresponding primers was amplified 38 cycles, each cycle consisting of denaturation at $94^{\circ} \mathrm{C}$ for $30 \mathrm{sec}$, primer annealing at $58^{\circ} \mathrm{C}$ for $30 \mathrm{sec}$, and extension at $72^{\circ} \mathrm{C}$ for $1 \mathrm{~min}$. Cycles were preceded by incubation at $94^{\circ} \mathrm{C}$ for $2 \mathrm{~min}$, an extra incubation at $72^{\circ} \mathrm{C}$ for $5 \mathrm{~min}$ to ensure full extension of the product. The products of PCR were analyzed on $10 \mathrm{~g} / \mathrm{l}$ agarose gel electrophoresis.

Western blot analysis. Cells were harvested from the plates and resuspended in cold RIPA lysis buffer with freshly added $0.1 \mathrm{mg} / \mathrm{ml}$ phenylmethylsulfonyl fluoride and $1 \mathrm{mg} / \mathrm{ml}$ aprotinin. The mixtures were lysed on ice for $30 \mathrm{~min}$ and were spun at $12000 \mathrm{~g}$ for $15 \mathrm{~min}$ at $4^{\circ} \mathrm{C}$. Aliquots of cell extracts containing $35 \mu \mathrm{g}$ of protein were separated by sodium dodecyl sulfate-polyacrylamide gelelectrophoresis (SDS-PAGE) on a 10-12\% gel and transferred to polyvinylidene difluoride (PVDF) membranes (Millipore, Bedford, MA). The membranes were blocked with 5\% non-fat dry milk and then incubated with corresponding primary antibodies overnight at $4^{\circ} \mathrm{C}$ and secondary antibodies. ECL was performed according to the manufacturer's protocol. For all Western blots, equal loading of protein was verified by re-blotting of membranes for $B$-actin protein. For determination of translocation of cytochrome c from mitochondria to cytosol, cells were washed once with PBS and incubated with lysis buffer. The cells were lysed on ice for $30 \mathrm{~min}$ and were spun at $500 \mathrm{~g}$ for $5 \mathrm{~min}$ at $4^{\circ} \mathrm{C}$ to eliminate nuclei and unbroken cells. Then the sample was centrifuged at $12000 \mathrm{~g}$ for $15 \mathrm{~min}$ at $4^{\circ} \mathrm{C}$ to obtain the mitochondrial fraction. The primary antibodies: Bcl-2, Bax, caspase-3, caspase-9, IL-24, PARP, cytochrome c were purchased from Santa Cruz Biotechnology (Santz Cruz, CA, USA).

Apoptosis and necrosis assay (Annexin-V-PI assay). Cells were trypsinized (washed twice with cold PBS. Aliquots of cell $\left(1 \times 10^{6}\right)$ were resuspended $(400 \mu 1)$ and stained with Annexin-V-FITC (Bipec Biopharma Co., USA) according the manufacturer's instructions. Propidium iodide (PI) was added to the samples after staining with Annexin-V to distinguish late apoptotic and necrotic cells. Flow cytometry (Becton-Dickinson, San Jose, CA, USA) was performed immediately after staining.

Xenograft growth inhibition assay. BALB/c nude mice (4 weeks old, 20-25 g) were purchased from the Shanghai Experiment Animal Center of the Chinese Academy of Sciences. The use and care of animals followed the guidelines of the Ethics Committee of Xinhua Hospital, School of Medicine, Shanghai Jiaotong University. Twenty-four nude mice whose tumors were similar in size (4-5 $\mathrm{mm}$ in diameter) were chosen and equal numbers were assigned to four groups: PBS, Ad.IL-24, Ad.GFP and control group. Ad.IL-24 or Ad.GFP was administered by means of intratumor single point injection at a dose of $2 \times 10^{8} \mathrm{pfu} / 100 \mu \mathrm{l}$ for each tumor separated every 3 days. 


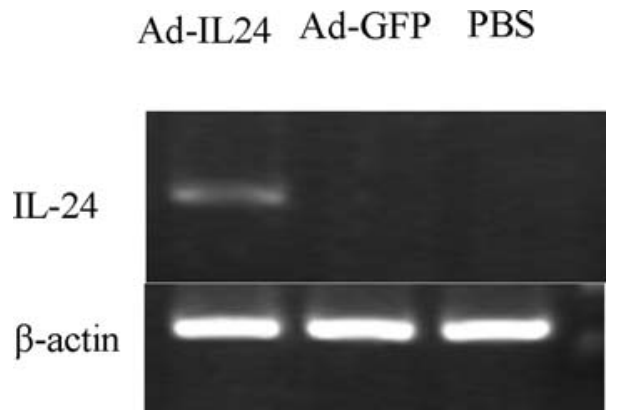

Figure 1. Expression of mda-7/IL-24 in GBC-SD cells infected Ad-IL24. Expression of IL-24 mRNA in GBC-SD cells were detected by RT-PCR. Total RNA was obtained from GBC-SD cells infected with Ad.IL-24, Ad.GFP and PBS which were as control. The first-strand cDNA was synthesized from RNA, using RT-PCR wre conducted by using primer sets for IL-24 and the control housekeeping gene, $B$-actin.

\section{Ad-IL24 Ad-GFP PBS}

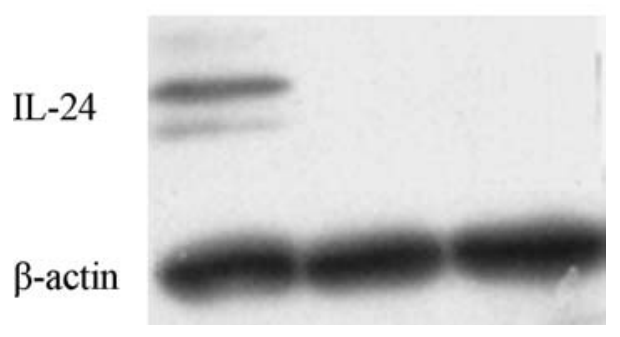

Figure 2. Expression of IL-24 protein in GBC-SD cells were detected by Western blotting. Lane 1, Ad.IL-24 tansfected cells; lane 2, AdGFP transfected cells; lane 3 , uninfected cells.

The animals were sacrificed 3 weeks after the first injection. The tumor was measured for i) the maximum diameter and ii) the minimum diameter. Tumor volume was calculated according to the formula: tumor volume $=\mathrm{ax} \mathrm{b}^{2} / 2$.

Statistical analysis. The data are expressed as means \pm SD and either ANOVA or Student's t-test was used for the analysis. $\mathrm{P}<0.05$ was considered statistically significant.

\section{Results}

Expression of IL-24 in GBC-SD cells. Before the start of the experiment, the endogenous level of IL-24 and the transduction efficiencies of Ad-IL24 were determined. RT-PCR and Western blot analysis demonstrated there were no endogenous IL-24 mRNA or protein expressed in GBC-SD cells. More the transfection efficiency was over $85 \%$ when we infected cells with $10 \mathrm{vp} / \mathrm{cell}$ of Ad-IL24 (data not shown) and IL-24 mRNA and protein were stably expressed in GBC-SD cells but not in cells treated with Ad.GFP or PBS (Figs. 1 and 2).

IL-24 inhibits gallbladder cancer cell proliferation by inducing apoptosis. To investigate the cytotoxic effects of Ad-IL24 on gallbladder cancer cells in vitro, the GBC-SD cells growth were examined using the MTT assay 3 days after virus transduction. Ad-IL24 treatment significantly inhibited GBC-SD

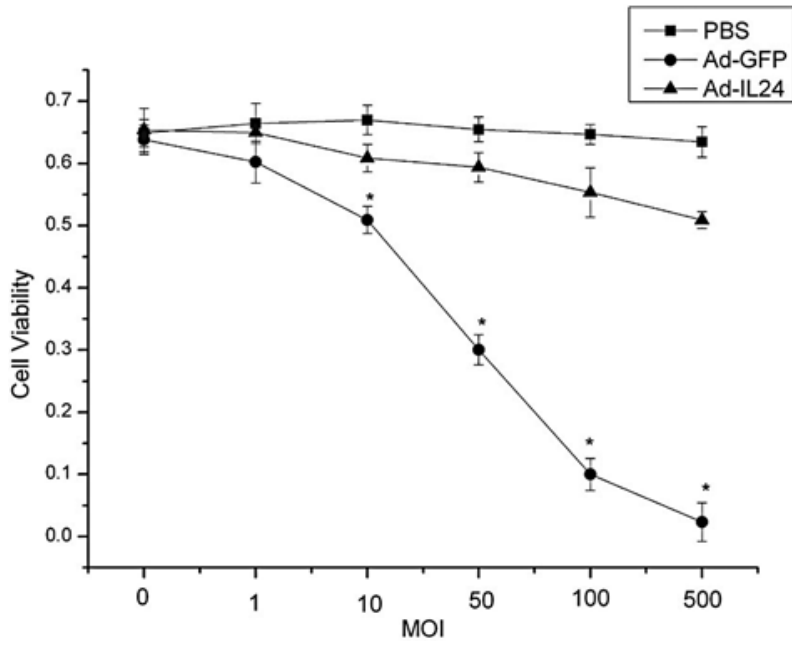

Figure 3. Cytotoxic effects of adenovirus mediated mda-7/IL-24. The GBC-SD cells were treated with Ad.IL-24 or Ad-GFP at multiples of infection of 0,1 , $10,50,100,500$ or PBS serving as the control at 3 days after infection. The survival cells were evaluated by using the MTT assay. The cell growth in vitro of GBC-SD cells treated with Ad.IL-24 was significantly inhibited at MOI of $10,50,100,500$ after infection. ${ }^{*} \mathrm{P}<0.05$ vs. cohorts of the control group (Student's t-test).

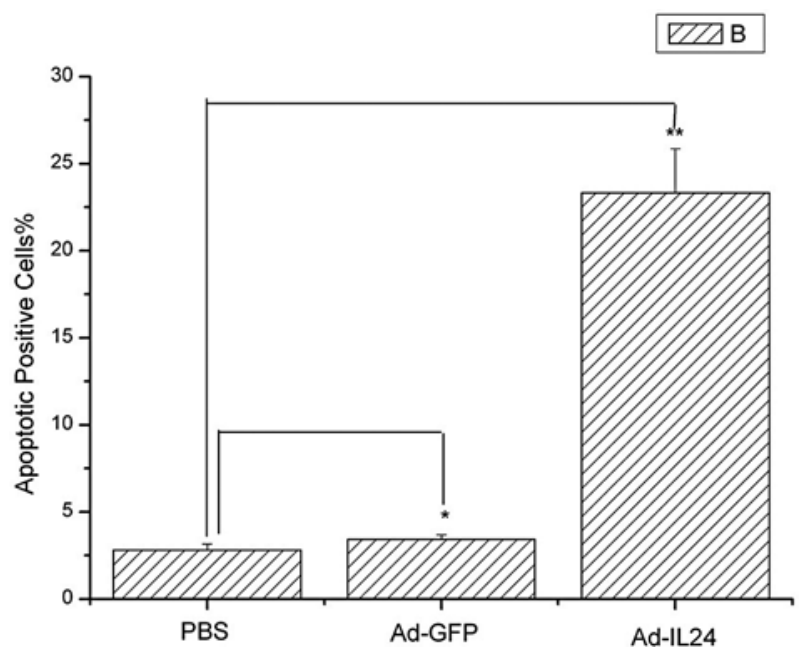

Figure 4. Apoptosis analysis by flow cytometry. The GBC-SD cells were transfected with Ad.IL-24, Ad.GFP or PBS for $72 \mathrm{~h}$ and then analyzed by flow cytometry. The number of apoptotic cells was significantly higher in the AdIL-24 group than that in the Ad.GFP or PBS groups, vs. cohorts of the control group (Student's t-test, $\mathrm{P}<0.05$ ).

cell growth in a dose-dependent manner, compared to the Ad.GFP-treated and PBS-treated control groups $(\mathrm{P}<0.05)$ (Fig. 3). These results showed that that Ad-IL24 significantly suppressed GBC-SD cells growth in vitro. The mechanism that Ad.mda-7 applied to inhibit proliferation was further investigated. Associated with the induction of apoptosis in Ad-IL24-treated tumor cells, a great number of apoptotic GBC-SD cells were visible among the cells infected with AdIL24, compared to those infected with Ad.GFP or PBS cells $(\mathrm{P}<0.05)$. There were no significant differences between the cells infected with Ad.GFP and treated with PBS ( $>>0.05$ ). The data indicated that Ad-IL24 induced apoptosis in GBCSD cell, as shown in Fig. 4. The ability of Ad-IL24 to induce 


\section{PBS Ad-GFP Ad-IL24}

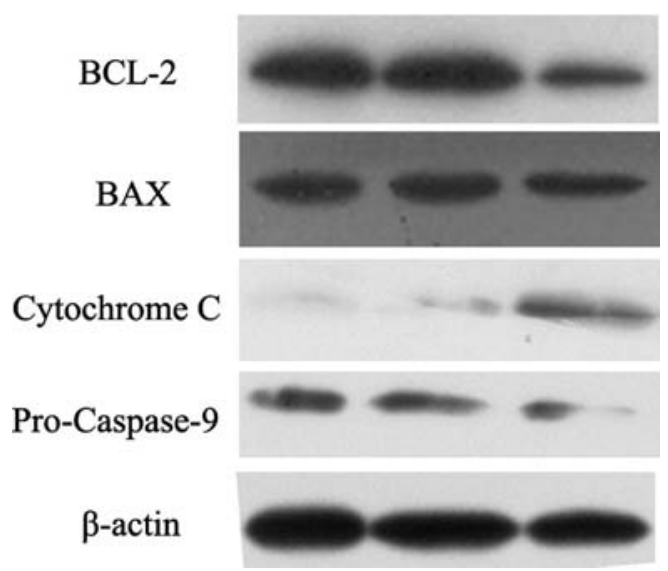

Figure 5. Activation of the apoptotic signaling pathway by mda-7/IL-24 Apoptotic proteins Bcl-2 and anti-apoptotic protein Bax and cytochrome c and pro-caspase- 9 were detected by Western blot analysis at 3 days after AdIL-24 infection in GBC-SD cells.

\section{PBS Ad-GFP Ad-IL24}

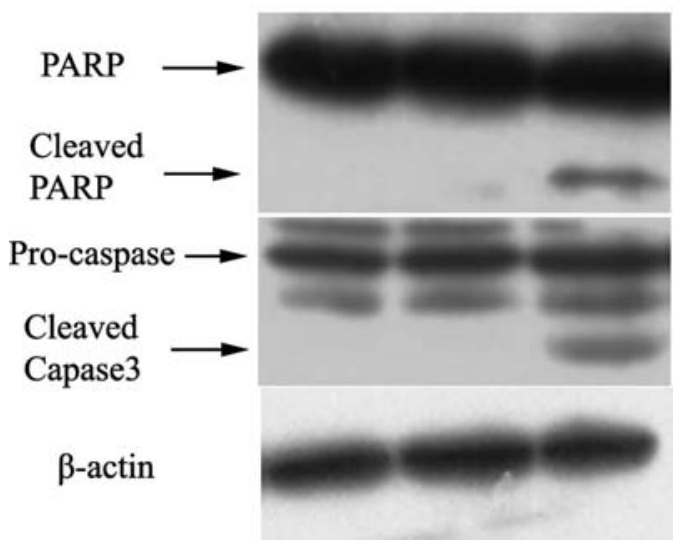

Figure. 6. Activation of the apoptotic signaling pathway by mda-7/IL-24 Pro-caspase 3 and cleaved of caspase- 3 and poly (ADP-ribose) polymerase (PARP) were detected at 3 days after Ad-IL24 infection in GBC-SD cells.

apoptosis is similar to these observed by others in some other tumor types (20).

IL-24-induced mitochondrial apoptosis pathways correlate with the down-regulation of $\mathrm{Bcl}-2$ and cytochrome c release. Bcl-2, Bcl-xL and other apoptosis-preventing members of the family inhibit the activation of mitochondria, whereas the pro-apoptotic Bcl-2 homologs Bax, Bak and Bok promote the release of cytochrome $\mathrm{c}$ and initiate the mitochondrial permeability shift transition $(21,22)$. We therefore tried to determine whether the infection of gallbladder tumor cells with Ad-IL24 altered the expression of the proteins associated with apoptosis pathway. As shown in Fig. 5, expression levels of Bcl-2 were markedly decreased after Ad-IL24 infection comparing with control cells. These results showed that the Ad-IL24 caused down-regulation of Bcl-2 expression. We also examined Bax expression levels and Ad-IL24 seemed not to have any effect on Bax expression. In addition, the release of cytochrome $\mathrm{c}$ from the mitochondria into the cytoplasm

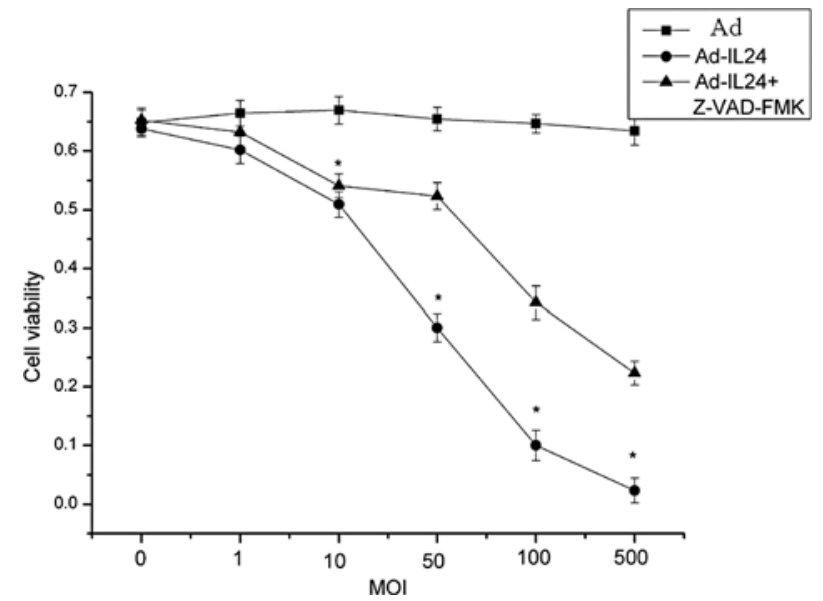

Figure 7. Inhibition of GBC-SD tumor growth in vivo. Athymic nude mice bearing GBC-SD tumors $\left(100-150 \mathrm{~mm}^{3}\right)$ were intratumorally injected with Ad-IL24 $\left(2 \times 10^{8} \mathrm{pfu} / 100 \mu \mathrm{l}\right)$, Ad-GFP $\left(2 \times 10^{8} \mathrm{pfu} / 100 \mu \mathrm{l}\right)$ or PBS every three day for a total of three times respectively. The tumor volumes were measured 0-18 days after injection. Ad-IL24 significantly inhibits the GBC-SD tumor growth in vivo, vs. cohorts of the control group (Student's t-test $\mathrm{P}<0.05$ ).

was observed in Ad-IL24 infected GBC-SD cells. These results indicated that Ad-IL24-might induce the apoptosis of GBC-SD via the activation of mitochondria-mediated apoptotic pathway by inhibiting Bcl-2, but not Bax.

IL-24 activates caspases to induce apoptosis and is inhibited by pancaspase inhibitor in gallbladder cancer cells. Cytochrome c along with Apaf-1 activates caspase-9, and caspase-9 can activate downstream caspases (23). To further confirm that expression of IL-24 is capable of inducing the mitochondrial apoptosis pathway; the activation of caspases was studied by Western blot analysis. Pro-caspase- 3 and procaspase- 9 were decreased and the cleavage of caspase- 3 was detected after Ad-IL24 infection. Cleavage of PARP, a substrate for the caspases, was also observed in Ad-IL24 infected cells (Fig. 6). To determine the role of caspases in IL-24-mediated tumor cell death, we used pancaspase inhibitor, Z-Val-Ala-DL-Asp-fluoromethylketone (Z-VAD-FMK; Alexis Biochemicals), to examine if the blocking of the activation of capase could compromise Ad-IL24-induced apoptosis. As shown in Fig. 8A, the caspase inhibitor was capable of partially inhibiting apoptosis after Ad.IL24 infection (Fig. 7). These results indicated that the classic caspase cascade is mainly responsible for IL-24-induced cell death. To verify the role of Bcl-2 in the Ad-IL24 induced mitochondrial apoptosis pathway, GBC-SD cells were infected with Ad-IL24 after treatment of GBC-SD cells with Z-VAD-FMK. Seventy-two hours after infection, cells were harvested and mitochondrial proteins and cytoplasmic proteins were extracted. As shown in Fig. 8B, we observed great reversion of Bcl-2 in cells treated with Z-VAD-FMK, whereas no reversion of Bcl-2 was found in tumor cells. After Z-VAD-FMK treatment, the release of cytochrome c into the cytoplasm was blocked, but cytochrome $\mathrm{c}$ in mitochondria was increased.

IL-24 suppresses tumor growth in vivo. Treatment of nude mice bearing GBC-SD tumor cells with Ad.IL24 induced a signi- 
A

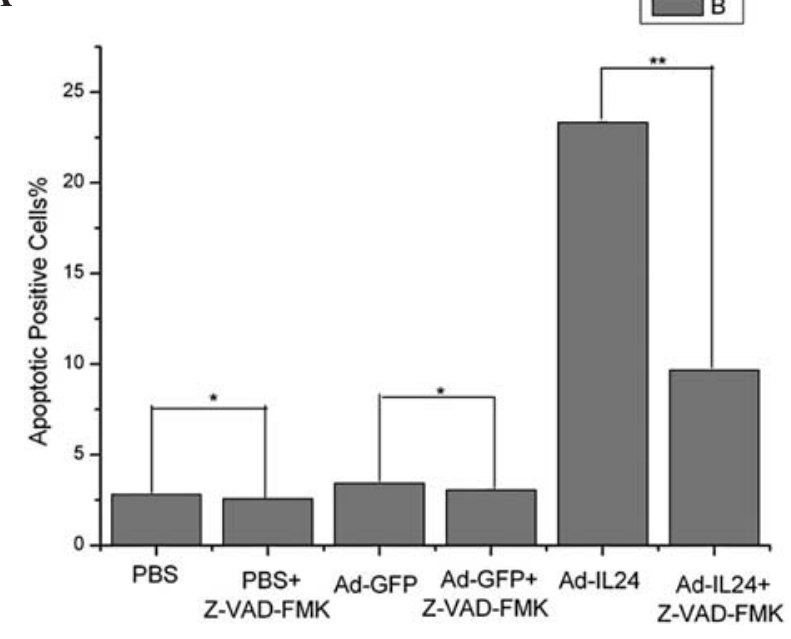

B

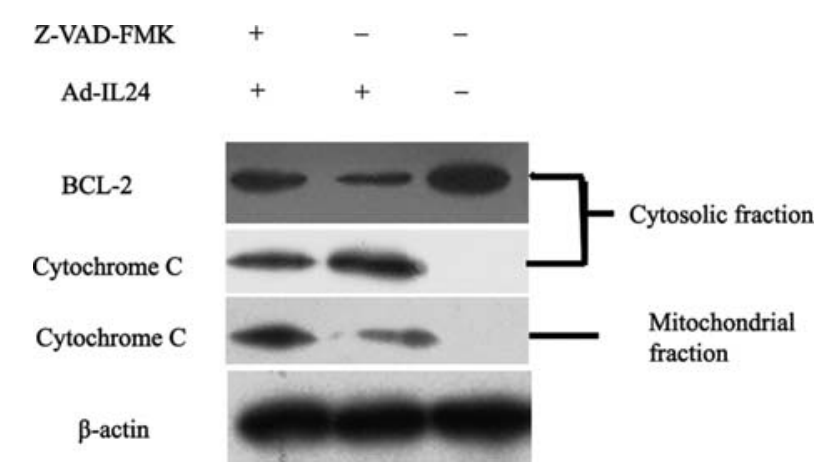

C

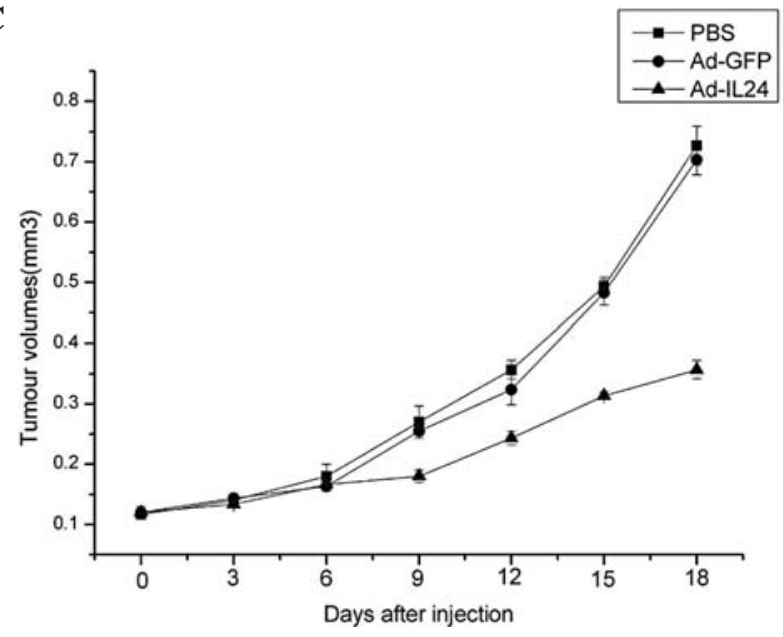

Figure 8. Inhibition of cell apoptosis by pancaspase inhibitor Z-VAD-FMK (A) Effect of Z-VAD-FMK on the viability of GBC-SD cells. Z-VAD-FMK $(30 \mu \mathrm{M})$ was added $30 \mathrm{~min}$ before adenovirus infection $(\mathrm{MOI}=10)$. At $72 \mathrm{~h}$ after infection, cytotoxicity was analyzed by MTT assay as described in Materials and methods, vs. cohorts of the control group (Student's t-test $\mathrm{P}<0.05$ ). (B) Effect of Z-VAD-FMK on the apoptosis of GBC-SD cells. $\mathrm{Z}$-VAD-FMK $(30 \mu \mathrm{M})$ was added $30 \mathrm{~min}$ before adenovirus infection (MOI=10). At $72 \mathrm{~h}$ after infection, apoptosis was analyzed by flow cytometry as described in Materials and methods, vs. cohorts of the control group (Student's t-test $\mathrm{P}<0.05)$. (C) Inhibition of cytochrome $\mathrm{c}$ release by pancaspase inhibitor Z-VAD-FMK.

ficant reduction in tumor growth as compared with mice treated with AdGFP or PBS (Fig. 8C) $(\mathrm{P}<0.05)$. These results showed that Ad-IL24 can efficiently induce tumor growth suppression in vivo.

\section{Discussion}

Gallbladder carcinoma is the fifth most common gastrointestinal malignancy, with an incidence of 2.5 and 10 per 100,000 persons in the United States and Japan, respectively (24), the disease is only considered curable at its early stages (25). Owing to the lack of effective examination measures and early symptoms, most patients with gallbladder cancer are diagnosed at late stages. Despite recent advance in surgical resection techniques and innovation of chemotherapeutic agents, only a marginal advantage is seen in a limited number of patients. Most patients will progress to recurrence and metastasis which ultimately succumb to this disease. The long-term survival rate for most patients is <5\% (26). Given the fact that gallbladder cancer is very aggressive in clinical behavior, most patients have metastatic disease at the time of diagnosis. Thus, novel treatment modalities are imperative to improve treatment result and to prolong survival. Since gallbladder cancer is considered to be the result of multiple genetic alterations, molecular therapy including gene therapy would be a promising new therapeutic option in the treatment of gallbladder cancer. Our study using Ad-IL24 as a potential therapeutic agent for the treatment of gallbladder cancer verified that Ad-IL24 could inhibit the growth and proliferation of GBC-SD cells in vitro and tumor-bearing mice in vivo.

In this study, the replication-incompetent adenovirus vector carrying mda-7/IL-24 was successfully transfected into human gallbladder carcinoma cell line GBC-SD. In accordance with other reports that IL-24 could inhibit the growth of several other human tumor cell types $(27,28)$, the antitumor effects of Ad-IL24 were observed in vitro on GBC-SD cells and in vivo in human gallbladder tumor xenograft mouse models. However, there was no obvious inhibitory effect of Ad-IL24 on the growth of GBC-SD cells and human gallbladder tumor xenograft by Ad-GFP or PBS, which indicated that the observed inhibitory effect on gallbladder cancer was due to the presence of IL-24.

Apoptosis reflects a balance between molecular and signaling events that either triggering programmed death or promotes survival. Most anti-cancer agents can activate the mitochondrial pathway to induce apoptosis, which is tightly controlled by proteins of the Bcl-2 family (29). Additionally, infection with Ad-IL24 induced changes in the ratio of proapoptotic (Bax and Bak) to anti-apoptotic (Bcl-2 and/or Bcl-xL) members of the Bcl-family, promoting a shift from survival to programmed cell death (30). To understand the underlying mechanism of tumor killing mediated by Ad-IL24 in GBC-SD cells, we analyzed the effects of Ad-IL24 expression on the known anti-apoptotic gene Bcl-2 and the pro-apoptotic gene Bax. After infection with Ad-IL24, a significant down-regulation of Bcl-2 expression was detected comparing with PBS or Ad.GFP infected cells (Fig. 5). These results suggested that IL-24 expression could down-regulate $\mathrm{Bcl}-2$. It has been reported that Bax plays an important role in apoptotic pathway (31). The pro-apoptotic Bcl-2 homologs Bax, Bak and Bok promote release of cytochrome c and initiate the mitochondrial permeability shift transition (29). In contrast to our expectations, the level of Bax expression showed no obviously change after infection of Ad-IL24 
compared with PBS or Ad.GFP infected cells. This indicated that Ad-IL24-induced apoptosis in GBC-SD cells may activate the apoptotic pathway by blocking $\mathrm{Bcl}-2$ expression but not $\mathrm{Bax}$. Because $\mathrm{Bcl}-2$ is the key regulator of mitochondrial apoptotic pathway and is involved in the regulation of several important factors, either pro-apoptosis or anti-apoptosis including, XIAP, AIF or Endo G, we further examined which molecules were downstream effectors of Ad-IL24 and Bcl-2.

Our study showed that expression of Ad-IL24 induced the release of cytochrome $\mathrm{c}$ and the activation of caspase, including the activation of procaspase- 9 and cleavage of caspase-3 and PARP, a substrate for the caspases (Fig. 6). The elevated cytochrome c was observed after infecting GBC-SD with Ad-IL24 (Fig. 5). Furthermore, the release of cytochrome $\mathrm{c}$ was inhibited after the treatment with Z-VADFMK which is a known cytochrome c inhibitor (Fig. 8C). In summary, these data suggested that overexpression of AdIL24 resulted the down-regulation of Bcl-2, but not Bax, which resulted in the release of cytochrome c. In addition, the presence of Z-VAD-FMK the inhibitor of cytochrome c, antagonizing apoptosis and the inhibitory effect of Ad-IL24 on the growth of GBC-SD, which further confirmed that caspases are required for the induction of apoptosis mediated by Ad-IL24. Our study proved that the mitochondrial apoptosis pathway plays an important role in apoptosis of GBC-SD cells induced by Ad-IL24.

It has been reported that Ad-IL24 could up-regulate the expression of a protein related to ER stress and kill cancer cells by causing endoplasmic reticulum (ER) stress (13,32-34), which raised questions regarding the relationship of the mitochondrial apoptosis pathway and ER stress; whether the AdIL24 mediated mitochondrial apoptosis pathway is regulated by ER stress and how they interacted with each other, and how the expression of Ad-IL24 could downregulate Bcl-2. Our current study investigated the relationship between the mitochondrial pathway and ER stress in gallbladder cancer cells.

In conclusion, Ad-IL24 could induce mytochrome c release and subsequent caspase activation resulting mitochondrial apoptotis in GBC-SD cells and growth inhibition of gallbladder cancer xenograft mice. As a result, Ad-IL24 might be a potential candidate to be used as an novel antitumor therapeutic agent in the treatment of gallbladder cancer.

\section{Acknowledgements}

This study was supported in part by Science and Technology Commission of Shang-hai Municipality (No.08JC1416200). We thank Drs Qijun Qian, Hongping Wu and Linfang Li for their help (Department of Viral and Gene Therapy Center, Eastern Hepatobiliary Surgery Hospital, The Second Military Medical University).

\section{References}

1. Misra S, Chaturvedi A, Misra NC and Sharma ID: Carcinoma of the gallbladder. Lancet Oncol 4: 167-176, 2003.

2. Grobmyer SR, Lieberman MD and Daly JM: Gallbladder cancer in the twentieth century: single institution's experience. World J Surg 28: 47-49, 2004.
3. Todoroki T: Chemotherapy for gallbladder carcinoma - a surgeon's perspective. Hepatogastroenterology 47: 948-955, 2000.

4. Jiang H, Lin JJ, Su ZZ, Goldstein NI and Fisher PB: Subtraction hybridization identifies a novel melanoma differentiation associated gene, mda-7, modulated during human melanoma differentiation, growth and progression. Oncogene 11: 2477-2486, 1995.

5. Huang EY, Madireddi MT, Gopalkrishnan RV, Leszczyniecka M, Su Z, Lebedeva IV, Kang D, Jiang H, Lin JJ, Alexandre D, Chen Y, Vozhilla N, Mei MX, Christiansen KA, Sivo F, Goldstein NI, Mhashilkar AB, Chada S, Huberman E, Pestka S and Fisher PB: Genomic structure, chromosomal localization and expression profile of a novel melanoma differentiation associated (mda-7) gene with cancer specific growth suppressing and apoptosis inducing properties. Oncogene 20: 7051-7063, 2001

6. Zheng M, Bocangel D, Ramesh R, Ekmekcioglu S, Poindexter N, Grimm EA and Chada S: Interleukin-24 overcomes temozolomide resistance and enhances cell death by down-regulation of O6methylguanine-DNA methyltransferase in human melanoma cells. Mol Cancer Ther 7: 3842-3851, 2008.

7. Lebedeva IV, Su ZZ, Vozhilla N, Chatman L, Sarkar D, Dent P, Athar M and Fisher PB: Mechanism of in vitro pancreatic cancer cell growth inhibition by melanoma differentiationassociated gene-7/interleukin-24 and perillyl alcohol. Cancer Res 68: 7439-7447, 2008.

8. Park MA, Yacoub A, Sarkar D, Emdad L, Rahmani M, Spiegel S, Koumenis C, Graf M, Curiel DT, Grant S, Fisher PB and Dent P: PERK-dependent regulation of MDA-7/IL-24-induced autophagy in primary human glioma cells. Autophagy 4: 513-515, 2008

9. Yan S, Zhang H, Xie Y, Sheng W, Xiang J, Ye Z, Chen W and Yang J: Recombinant human interleukin-24 suppresses gastric carcinoma cell growth in vitro and in vivo. Cancer Invest 28: 85-93, 2010.

10. Liu J, Sheng W, Xie Y, Shan Y, Miao J, Xiang J and Yang J: The in vitro and in vivo antitumor activity of adenovirusmediated interleukin-24 expression for laryngocarcinoma. Cancer Biother Radiopharm 25: 29-38, 2010.

11. Gupta P, Su ZZ, Lebedeva IV, Sarkar D, Sauane M, Emdad L, Bachelor MA, Grant S, Curiel DT, Dent P and Fisher PB: mda-7/ IL-24: multifunctional cancer-specific apoptosis-inducing cytokine. Pharmacol Ther 111: 596-628, 2006.

12. Cunningham CC, Chada S, Merritt JA, Tong A, Senzer N, Zhang Y, Mhashilkar A, Parker K, Vukelja S, Richards D, Hood J, Coffee $\mathrm{K}$ and Nemunaitis J: Clinical and local biological effects of an intratumoral injection of mda-7 (IL24; INGN 241) in patients with advanced carcinoma: a phase I study. Mol Ther 11: 149-159, 2005.

13. Sauane M, Su ZZ, Gupta P, Lebedeva IV, Dent P, Sarkar D and Fisher PB: Autocrine regulation of mda-7/IL-24 mediates cancerspecific apoptosis. Proc Natl Acad Sci USA 105: 9763-9768, 2008.

14. Sainz-Perez A, Gary-Gouy H, Gaudin F, Maarof G, MarfaingKoka A, De Revel T and Dalloul A: IL-24 induces apoptosis of chronic lymphocytic leukemia B cells engaged into the cell cycle through dephosphorylation of STAT3 and stabilization of p53 expression. J Immunol 181: 6051-6060, 2008.

15. Gopalan B, Litvak A, Sharma S, Mhashilkar AM, Chada S and Ramesh R: Activation of the Fas-FasL signaling pathway by MDA-7/IL-24 kills human ovarian cancer cells. Cancer Res 65: 3017-3024, 2005.

16. Yacoub A, Park MA, Gupta P, Rahmani M, Zhang G, Hamed H, Hanna D, Sarkar D, Lebedeva IV, Emdad L, Sauane M, Vozhilla N, Spiegel S, Koumenis C, Graf M, Curiel DT, Grant S, Fisher PB and Dent P: Caspase-, cathepsin- and PERK-dependent regulation of MDA-7/IL-24-induced cell killing in primary human glioma cells. Mol Cancer Ther 7: 297-313, 2008.

17. Ekmekcioglu S, Mumm JB, Udtha M, Chada S and Grimm EA: Killing of human melanoma cells induced by activation of class I interferon-regulated signaling pathways via MDA-7/IL-24. Cytokine 43: 34-44, 2008.

18. Park MA, Walker T, Martin AP, Allegood J, Vozhilla N, Emdad L, Sarkar D, Rahmani M, Graf M, Yacoub A, Koumenis C, Spiegel S, Curiel DT, Voelkel-Johnson C, Grant S, Fisher PB and Dent P: MDA-7/IL-24-induced cell killing in malignant renal carcinoma cells occurs by a ceramide/CD95/PERKdependent mechanism. Mol Cancer Ther 8: 1280-1290, 2009.

19. Prieto J, Qian C, Hernandez-Alcoceba R, GonzalezAseguinolaza G, Mazzolini G, Sangro B and Kramer MG: Gene therapy of liver diseases. Expert Opin Biol Ther 4: 1073-1091, 2004. 
20. Mhashilkar AM, Stewart AL, Sieger K, Yang HY, Khimani AH, Ito I, Saito Y, Hunt KK, Grimm EA, Roth JA, Meyn RE, Ramesh R and Chada S: MDA-7 negatively regulates the betacatenin and PI3K signaling pathways in breast and lung tumor cells. Mol Ther 8: 207-219, 2003.

21. Harris $\mathrm{MH}$ and Thompson CB: The role of the Bcl-2 family in the regulation of outer mitochondrial membrane permeability. Cell Death Differ 7: 1182-1191, 2000.

22. Adams JM and Cory S: The Bcl-2 apoptotic switch in cancer development and therapy. Oncogene 26: 1324-1337, 2007.

23. Cain K, Bratton SB and Cohen GM: The Apaf-1 apoptosome: a large caspase-activating complex. Biochimie 84: 203-214, 2002.

24. Pitt HA, Dooley WC, Yeo CJ and Cameron JL: Malignancies of the biliary tree. Curr Probl Surg 32: 1-90, 1995.

25. Donohue JH, Stewart AK and Menck HR: The national cancer data base report on carcinoma of the gallbladder, 1989-1995. Cancer 83: 2618-2628, 1998

26. Schauer RJ, Meyer G, Baretton G, Schildberg FW and Rau HG: Prognostic factors and long-term results after surgery for gallbladder carcinoma: a retrospective study of 127 patients. Langenbecks Arch Surg 386: 110-117, 2001.

27. Mhashilkar AM, Schrock RD, Hindi M, Liao J, Sieger K, Kourouma F, Zou-Yang XH, Onishi E, Takh O, Vedvick TS, Fanger G, Stewart L, Watson GJ, Snary D, Fisher PB, Saeki T, Roth JA, Ramesh R and Chada S: Melanoma differentiation associated gene-7 (mda-7): a novel anti-tumor gene for cancer gene therapy. Mol Med 7: 271-282, 2001.

28. Ramesh R, Saeki T, Templeton NS, Ji L, Stephens LC, Ito I, Wilson DR, Wu Z, Branch CD, Minna JD and Roth JA: Successful treatment of primary and disseminated human lung cancers by systemic delivery of tumor suppressor genes using an improved liposome vector. Mol Ther 3: 337-350, 2001.
29. Hsu YT, Wolter KG and Youle RJ: Cytosol-to-membrane redistribution of $\mathrm{Bax}$ and $\mathrm{Bcl}-\mathrm{X}(\mathrm{L})$ during apoptosis. Proc Natl Acad Sci USA 94: 3668-3672, 1997.

30. Lebedeva IV, Su ZZ, Chang Y, Kitada S, Reed JC and Fisher PB: The cancer growth suppressing gene mda-7 induces apoptosis selectively in human melanoma cells. Oncogene 21: 708-718, 2002.

31. Cao XX, Mohuiddin I, Chada S, Mhashilkar AM, Ozvaran MK, McConkey DJ, Miller SD, Daniel JC and Smythe WR: Adenoviral transfer of mda-7 leads to BAX up-regulation and apoptosis in mesothelioma cells, and is abrogated by over-expression of BCL-XL. Mol Med 8: 869-876, 2002.

32. Hamed HA, Yacoub A, Park MA, Eulitt P, Sarkar D, Dimitriev IP, Chen CS, Grant S, Curiel DT, Fisher PB and Dent P: OSU-03012 enhances Ad.mda-7-induced gbm cell killing via ER stress and autophagy and by decreasing expression of mitochondrial protective proteins. Cancer Biol Ther. Apr 9, 2010 (Epub ahead of print).

33. Zhang X, Kang X, Shi L, Li J, Xu W, Qian H, Wu M and Yin Z: mda-7/IL-24 induces apoptosis in human HepG2 hepatoma cells by endoplasmic reticulum stress. Oncol Rep 20: 437-442, 2008.

34. Sauane M, Su ZZ, Dash R, Liu X, Norris JS, Sarkar D, Lee SG, Allegood JC, Dent P, Spiegel S and Fisher PB: Ceramide plays a prominent role in MDA-7/IL-24-induced cancer-specific apoptosis. J Cell Physiol 222: 546-555, 2010. 